\title{
EDITORIAL
}

\section{Ethical conflicts of interest in modern biomedicine?}

\author{
Josef Berger \\ Department of Preclinical Research, Faculty of Health and Social Studies, University of South Bohemia in České \\ Budějovice, Czech Republic
}

\begin{abstract}
Summary
We try to select the main ethical problems which occur as the consequence of new biotechnologies in biomedicine. These technologies offer benefits for health and the social economy but there is also a risk of contraveninghuman rights principles.
\end{abstract}

Keywords: bioethics - human rights - biotechnology - animal - biological samples

From the perspective of 'biomedicine' as the application of biological research into clinical practice we find that there are three complex questions concerning ethical problems.

(i) Each new fact which brings a benefit also represents a risk of adverse effects and ethical problems in the selection of patients (cf. Issa 2003, Rosenblatt 2003). Clinical studies pose problems of ethical behaviour in research (Olsen at al. 2003). The solution of these problems requires collaboration between physicians, nurses, and philosophers. Although the results of these debates affect biomedical research particularly with respect to financial support and legislative restrictions on further work biologists usually have no direct influence on the outcomes.

(ii) Problems caused by new biotechnologies involving manipulation of parts of a human body at the level of genes, cells, and tissues are arbitrated through discussion among physicians, philosophers, jurists and biologists (cf. Jansen 2002). This debate must comprise the clarification both of known mechanisms of phenomena studied in the living system and current limitations on our knowledge our uncertainty is frequently larger than our knowledge (e.g. for cell biology see Smetana 2003).

(iii) The third group of ethical questions of biomedicine lies within the framework of animal protection. Legislative rules concerning so-called 'animal rights' resulting from discussions among veterinarians, biologists, economists, philosophers and politicians are common in many countries (cf. Kromka 2003).

Recent literature shows that the highest number of indexed papers in the ISI Web of Science and Medline debate the problems mentioned above in the second group, i.e. bioethical consequences and controversies concerning new biotechnologies such as genetic testing including pre-implantation, gene therapy, human embryonic stem cell transplantation as well as the use of cord blood as the source of haemopoietic stem cells, and reproductive cloning (cf. Viville et al. 1998, Bailey 2001, Johnson 2001, Jones and Kessel 2001, Roy 2001, Burgio et al. 2003, Rabino 2003).

Each of these new biotechnologies will bring both a benefit and an abuse in the future and we need laws which define the frontiers of legal manipulations. The making of good laws is not an easy matter as it is both demanding and controversial to establish international biomedical standards and to make bridges between cultural, religious and political interests. The redefinition of the onset of being and death (Messikomar at al. 2001, Ye at al. 2001, Lenoir 2002, Erwin 2003) is often at the centre of such discussion as these definitions must be integrated into the principles of human rights. 
Good results were achieved in bioethics concerning the use of human 'biologic' materials in research. Scientists using human tissues samples, cells or genes should follow respect for persons, beneficence and justice (Sobel 1999) to reach an appropriate balance between personal autonomy and social need. A widespread consensus exists on preventing human germ-line interventions and human reproductive cloning (Andorno 2002).

It is impossible to refer to all ethical problems of biomedicine in one paper. Generally, biomedical research presents possibilities of benefits for human health and social economy but always at the risk of health injury. Discussion on these risks could restrict certain paths of biomedical research and, therefore, be unpopular with biologists. Nevertheless, the early detection of both benefit and risk can accelerate bioethical rules which make it possible to concentrate both effort and changes into desirable research areas.

\section{ACKNOWLEDGEMENTS}

This work was supported by the Ministry of Education of Czech Republic (grant no.1894/03)

Published online $3^{\text {rd }}$ October 2003.

\section{REFERENCES}

Adorno R.: Biomedicine and international human rights law: in search of global consensus. Bull. WHO 80: 959-963, 2002.

Bailey R.: Deciding about your health care: the ethicist as policy-maker. Health Care Anal. 9: 265-281, 2001.

Burgio G.R., E. Gluckman, F. Locatelli: Ethical reappraisal of 15 years of cord-blood transplantation. Lancet 361: 250-252, 2003.

Erwin C.G.: Embryonic stem research: one small step for science or one giant leap back for manking? Univ. Illinois Law Rev., pp. 211-243, 2003.

Fallena-Zonana M. and M. Kraus-Weisman: Medicine: conflicts of interests in medical research. Riv. Invest. Clin. 55: 339-346, 2003.

Issa A.M.: Pharmacogenomic profiling in postmarketing surveillance: prospects and challenges. Pharmacogenomics 4: 647-655, 2003.

Jansen B.: Modern medicine and biotechnology: an ethical conflict of interest? Sci. Engineer. Ethics 8: 319-325, 2002.

Johnson M.H.: Reproduction in the Noughties: will the scientists have all the fun? J. Anat. 198: 385-398, 2001.

Jones S.F. and A.S Kessel: The 'Redefinition of death' debate: western concepts and western bioethics. Sci. Engineer. Ethics 7: 63-75, 2001.

Kromka F.: Equality for man and animal - A common-sense criticism of this animal rights concept. Berich. Landwirtsch. 81: 150-158, 2003.

Lenoir N.: Bioethics in the XXIst century - the jurist's point of view. Presse med. 31: 565-571, 2002.

Messikomer C.M., R.C. Fox, J.P. Swazey: The presence and influence of religion in American bioethics. Prospect.Biol.Med.44: 485-508, 2001.

Olsen D.P., A. Davis, V. Tschudin, G.Hunt, A.J.G. van der Arend: Ethical considerations in international nursing reseach: a report from the International Centre for Nursing Ethics. Nurs. Ethics 10: 122-137, 2003.

Rabino I.: Gene therapy: ethical issues. Theor. Med. Bioethics 24: 31-58, 2003.

Richter G. and M.D. Bacchetta: Interventions in the human genome: some moral and ethical considerations. J. Med. Philos. 23: 303-317, 1998.

Rosenblatt M.: Is it ethical to conduct placebocontrolled clinical trials in the development of new agents for osteoporosis? An industry perspective. J. Bone Min. Res. 18: 1142-1145, 2003.

Roy I.: Ethical considerations in the use of lentiviral vectors for genetic transfer. Som. Cell Mol. Genet. 26: 175-191, 2001.

Smetana K.: To the mystery of cell biology. J. appl. Biomed. 1: 51-53, 2003.

Sobel M.E.: Ethical issues in molecular pathology paradigms in flux. Arch. Pathol. Lab. Med. 123: 1076-1078, 1999.

Viville S., N. Messaddeq, E. Flori, P. Gerlinger: Preparing for preimplantation genetic diagnosis in France. Human Repr. 13: 1022-1029, 1998.

Ye X.H., M. Mitchell, K. Newman, M.L. Batshaw: Prospects for prenatal gene therapy in disorders causing mental retardation. Mental Retard. Develop. Disab. Res. Rev. 7: 65-72, 2001.

\section{* Address:}

Josef Berger, Faculty of Health and Social Studies, University of South Bohemia, Branišovská 31, 37005 České Budějovice, Czech Republic; berger@jcu.cz 